\title{
Turner Sendromunda Fertilite Durumu ve İnfertilite Hemşiresinin Rolleri
}

\author{
Fertility Status in Turner Syndrome and the Roles of the Infertility Nurse
}

\author{
Meryem ÖNGEN* iD, Fatma BAŞAR** iD
}

\begin{abstract}
ÖZET
Turner Sendromu, gonozomlardaki X kromozomlarından birinin tam veya klsmi kaybı ya da 46,XY kromozomlu fetüslerde $Y$ kromozomu kaybı sonucunda gelişen kromozomal bir bozukluktur. Turner Sendromlu olguların yaklaşık \%50'sinde 45,X karyotip bulunmaktadır ve bu olguların çoğunda prematür ovaryen yetmezlik durumu mevcut olabilir. Olguların sadece \%10'unda spontan pubertel gelişimin tamamlanabildiği ve \%2'sinde spontan gebeliğin oluşabildiği bildirilmiştir. Turner Sendromu, üreme sistemi ve diğer sistemler üzerindeki etkileri düşünüldüğ̈̈nde dikkatli bir şekilde ele alınmasi gereken önemli bir kromozomal anomalidir. Sendromun tipine bağll olarak spontan menarş ve gebelik gelişebileceği gibi hormon replasmanı ve/veya yardımcı üreme teknikleri yardımıyla da fertilite sağlanabilmektedir. Infertilite hemşirelerinin, yardımcı üreme teknikleri ile tedavi gören Turner Sendromlu bireylerin bilgi ihtiyaçlarını gidermeleri ve bireyleri gerekli psikolojik ve psikoseksüel destek alabilecekleri kaynaklara yönlendirmeleri gerekmektedir.
\end{abstract}

Anahtar Kelimeler: Fertilite, Gebelik, Hemşirelik, Turner sendromu

\begin{abstract}
Turner Syndrome is a chromosomal disorder that develops as a result of the complete or partial loss of one of the $X$ chromosomes in the gonosomes or the loss of the Y chromosome in fetuses with 46, XY chromosomes. Approximately 50\% of the syndromed cases have 45, X karyotype and premature ovarian failure may be present in most of these cases. It has been reported that spontaneous pubertal development can be completed in only $10 \%$ of the cases and spontaneous pregnancy can occur in $2 \%$. Turner Syndrome is an important chromosomal abnormality that should be handled carefully considering its effects on the reproductive system and other systems. Depending on the type of the syndrome, spontaneous menarche and pregnancy can develop, as well as fertility can be achieved with the help of hormone replacement and/or assisted reproductive techniques. Infertility nurses need to meet the information needs of individuals with Turner Syndrome who are treated with assisted reproductive techniques and direct them to the resources they can get necessary psychological and psychosexual support.
\end{abstract}

Keywords: Fertility, Pregnancy, Nursing, Turner syndrome

* Araş. Gör., Akdeniz Üniversitesi Hemşirelik Fakültesi, Doğum ve Kadın Hastalıkları Hemşireliği Anabilim Dalı

*** Doç. Dr., Kütahya Sağlık Bilimleri Üniversitesi Sağlık Bilimleri Fakültesi, Hemşirelik Bölümü

Sorumlu Yazar / Corresponding Author: Meryem Öngen, ongenmeryem@gmail.com 


\section{GíRIŞ}

Turner Sendromu (TS), 46,XX kromozomlu fetüslerde X kromozomlarından birinin tam veya kısmi kaybı, 46,XY kromozomlu fetüslerde Y kromozomu kaybı sonucunda gelişen, 2500 canlı doğumda bir görülen cinsiyet kromozomu anomalisidir (Reindoller, 2011; Cadoret et al., 2018). Olguların yaklaşı \%50'sinde X kromozomlarından birinin tam kaybı mevcuttur. \%25'inde ise X kromozomlarından birinin bir parçasının kopup kaybolduğu kısmi delesyon durumu bulunmaktadır (Stochholm, Juul, Juel, Neaeraa, \& Gravholt, 2006).

Turner Sendromu ilk kez Ullrich (1930) tarafından tanımlanmıştır (Ullrich, 1930). Henry Turner tarafından ise 1938 yılında TS'nin tipik bulguları olan; kısa boy, dışa çarpık dirsek, ekstremitelerde lenfödem, gonadal disgenezi, primer ovaryen yetmezlik, perdeli boyun, geniş aralıklı meme uçları ve geniş göğüs kafesi gibi çeşitli sistemlere ait semptomları tanımlamıştır (Turner, 1938). Bunu takiben 1959 y1lında Ford ve ark. TS'nin gonozomal kromozom kaynaklı bir anomali olduğunu keşfetmişlerdir (Ford, Jones, Polani, de Almeida, \& Briggs, 1959).

Turner Sendromundan etkilenen fetüslerin yaklaşık \%55'inde ayrılamama sebebiyle Barr cisimciği negatiftir (Sadler, 2012). Bu fetüslerin de \%60-80'inde ayrlamamanın nedeninin erkek gametten kaynaklı olduğu belirtilmektedir (Pinsker, 2012). TS bulunan fetüslerin \%98'inin spontan abortus sonucunda kaybedildiği bildirilmiştir. Buna rağmen TS'nun, hayata uyum sağlayabilen tek monosomi türü olduğu belirtilmiştir (Sadler, 2012).

Prenatal tanılamada, ultrasonografi (USG) bulguları ve maternal serumda hormonların değerlendirilmesi gibi yöntemlerden faydalanılsa da kesin tanı için amniyosentez veya koryon villüs örneklemesi ile karyotip analizi yapılması gerekmektedir (Gravholt et al. 2017; Shankar \& Backeljauw, 2018). Ayrıca prenatal dönemde yapılan karyotip analizinin genellikle TS fenotipinin derecesini tam olarak belirleyemediği, postnatal dönemde de tanıyı ve hastalığın tipini doğrulamada yeniden karyotip analizinin yapılması gerektiği belirtilmiştir (Gunther, Eugster, Zagar, Bryant, \& Davenport, 2004; Bondy, 2007; Gil, Quezada, Revello, Akolekar, \& Nicolaides, 2015).

\section{Turner Sendromunda Fertilite Durumu}

\section{Turner Sendromunda Ovaryen Foliküllerin Gelişimi ve Kromozomal Anomaliler}

Turner Sendromunda, gebeliğin ilk trimesterinde fetüsün gelişimi normaldir. 14-18. haftalarda gonadal gelişimin normal olduğu ancak bu haftalardan kısa bir süre sonra oosit kaybının başladığı ve bu durumun doğuma kadar ya da doğumdan sonraki birkaç aya kadar devam ettiği bildirilmiştir (Reynaud et al. 2004; Saenger, 2008). 46,XX karyotipe sahip normal fetüslerde, 18. haftaya kadar overlerde ilkel germ hücreleri bulunurken, 20. haftadan sonra bu ilkel germ hücrelerinden primordial folliküllerin gelişimi başlar. 26. hafta civarında ise preantral ve antral folliküller overlerde görülmeye 
başlar. Ancak Turner Sendromuna sahip bazı fetüslerin overlerinde ilkel germ hücreleri bulunmasına rağmen bu ilkel germ hücrelerinde ileri gelişimin gerçekleşmediği belirtilmiştir (Reynaud et al. 2004).

Normal fiziksel ve seksüel gelişim için cinsiyet kromozomlarında yer alan psödootozomal bölgelerin karşılıklı olarak bulunması gerekmektedir (dişilerde XX ve erkeklerde XY şeklinde) (Urbach \& Benvenisty, 2009). Fiziksel özellikler ile ilişkili genlerin X kromozomunun kısa kolunda ve ovaryen fonksiyonları etkileyen genlerin ise $\mathrm{X}$ kromozomunun uzun kolunda yerleşik olduğu belirtilmiştir (Zinn et al. 1998; Schlessinger et al. 2002). TS'li olgularda X kromozomunun kısa veya uzun kolunda delesyon, halka kromozom ve izokromozom gibi yapısal anomaliler meydana gelebilmektedir. Ayrıca bu olgularda 45,X/46,XX, 45,X/46,XY ve 45,X/47,XXX gibi mozaisizm durumları da bulunabilir. TS'lu olguların yaklaşık \%50'sinde 45,X karyotip bulunduğu bildirilmiştir (Al Alwan et al. 2014). Olguların \%6-12'sinde ise Y kromozomu ile ilgili mozaisizm izlenmektedir (Gravholt et al. 2017). Bu olgularda Y kromozomunun yapısal olarak normal olabileceği gibi çeşitli sebeplere bağlı olarak anormal de olabileceği ifade edilmektedir (Radtke, Sauder, Rehm, \& McKenna, 2014).

En yaygın görülen $\mathrm{X}$ kromozom anomalisinin izokromozom durumu olduğu belirtilmiştir (Al Alwan et al. 2014). İzokromozom; iki kısa veya uzun koldan oluşan, sentromerden bölünme ile meydana gelen, hem delesyon hem de duplikasyonun mevcut olduğu yapısal bir kromozomal anomaliyi ifade eder. Uzun koldaki kromatidler izokromozom q, kısa koldaki kromatidler ise izokromozom p olarak isimlendirilir (Harel, Pehlivan, Caskey, \& Iupski, 2015). Mozaisizmin olduğu ya da olmadığı vakalarda izokromozom anomali sıklığının \%15-18 olduğu belirtilmiştir (Sybert \& McCauley, 2004). Delesyon ise; X kromozomunun uzun veya kisa kollarında yer alan genlerin koparak kaybolması sonucunda genetik materyal kaybının gerçekleşmesidir (Mercer et al., 2013). Halka kromozom durumunda ise kromozomun her iki ucunda meydana gelen terminal kırılma sonucu iki uç birbiri ile birleşir (Mercer et al., 2013). Halka kromozomlu olgularda, mitoz bölünme sırasında meydana gelen çeşitli değişimler nedeniyle sekonder kromozomal anormallikler gelişebilir ve halka kromozom kaybı veya kazancı meydana gelebilir. Bu durum sebebiyle fenotip özelliklerinin çeşitlilik gösterdiği belirtilmiştir (Glass et al., 2006; Hockner et al., 2008; Zollino et al., 2009; Sodre et al., 2010).

\section{Turner Sendromunun Fertiliteye ve Cinselliğe Etkisi}

TS'de fertilite azalmasının ya da fertilite kaybının nedeninin temel olarak hızlandırılmış germ hücre kaybı ve fetal hayatta bozulmuş folikülogenezden kaynaklandığı ve bunların sonucunda prematür foliküler tükenmenin meydana geldiği düşünülmektedir (Modi, Sane, \& Bhartiya, 2003; Reynaud et al. 2004). Ancak, oosit kaybının derecesinin değişken olduğu ve postnatal dönemde overlerin fonksiyonlarının, overlerde kalan 46,XX karyotipli hücrelerin yüzdesine bağlı olduğu tahmin edilmektedir (Grynberg et al., 2016). Ovaryen folikül kaybı ve postnatal dönemde meydana gelen 
gamet kaybı bir araya geldiğinde vakaların \%80'inden fazlasında cinsel gelişimin tamamlanamadığ ve ovaryen yetersizliğin meydana geldiği bildirilmiştir (Pasquino, Passeri, Pucarelli, Segni, \& Mnicchi, 1997). Bu durum, embriyonun implante olup geliştiği endometriyum ve uterusunda fonksiyonlarında yetersizliğe neden olmaktadır (Gravholt, 2004). TS'lu bireylerin \%95-98'inde tanımlanabilir bir over fonksiyonunun olmadığı prematür ovarian yetmezlik durumunun mevcut olduğu ve bu bireylerin çoğunun puberte döneminde hormon replasman tedavisine ihtiyaç duyduğu belirtilmektedir (Sybert \& McCauley, 2004). TS'lu bireylerde tespit edilen yüksek gonadotropin düzeyleri ovaryen yetmezliğe işaret etmektedir. 45,X karyotipli bireylerde FSH düzeyleri mozasizmi olan TS'lu bireylere kıyasla daha yüksektir. TS'lu bireylerin serum FSH ve LH düzeylerinde doğumdan hemen sonra yükselme olduğu görülmüştür. Benzer şekilde over fonksiyonlarında da azalmanın başladığı ve bu azalmanın menopoza kadar artarak devam ettiği belirtilmiştir (Hagen, Main, Kjaergaard, \& Juul, 2010). Benzer şekilde TS karyotipi ile AMH serum düzeyleri arasında bir ilişki olduğu düşünülmektedir. 46,XX mozaik olgularda, 45,X olgulara göre $\mathrm{AMH}$ düzeylerinin daha yüksek olduğu belirtilmiştir (Visser et al., 2013). AMH'nin over folliküler rezervinin tespitinde güvenilir bir hormonal belirteç olabileceği düşünülmektedir (Hagen et al., 2010; Broer, Broekmans, Laven, \& Fauser, 2014). Ancak çocukluk ve adölesan dönemleri ile ilgili verilerin yetersizliği nedeniyle, bu popülasyonlarda AMH değerlerinin dikkatli bir şekilde yorumlanması gerektiği belirtilmektedir (Kelsey, Wright, Nelson, Anderson, \& Wallace, 2011).

TS'lu bireylerin sadece \%33'ünde spontan puberte belirtilerinin meydana geldiği bildirilmiştir (Pasquino et al., 1997). Bu bireylerin ise yaklaşık \%10'unda spontan pubertel gelişimin tamamlanabildiği tespit edilmiştir (Hovatta, 1999). Genetik olarak 46,XX yapısının olduğu veya olmadığı 47,XXX mozaisizminin bulunduğu TS'li bireylerde pubertal gelişimin ve spontan menarşın meydana gelme olasılığının, X kromozomunun tam kaybının olduğu, mozaisizm bulunmayan, TS’lu bireylere göre daha fazla olduğu belirtilmektedir (Blair, Tolmie, Hollman, \& Donaldson, 2001; Sybert, 2002). Yapılan bir çalışmada 47, XXX mozaisizmi bulunan bireylerde spontan menarş olasılı̆̆ının 45,X/46,XX olan TS'lu bireylere kıyasla daha yüksek olduğu görülmüştür. Ancak bu bireylerin önemli bir kısmında normal menstrual döngünün devam etmediği, mozaik 46,XX ve 47,XXX bireylerde de sekonder amenore ve prematür ovaryen yetmezliğin geliştiği belirtilmiştir. Aynı şekilde gebelik ihtimali, mozaisizmin bulunduğu bireylerde 45,X'li bireylere kıyasla daha yüksek olsa da, canlı doğum oranlarının \%50'den az olduğu ifade edilmiştir (Sybert, 2002). 45, X karyotipli bireylerin \%14'ünde, 45,X/46,XX mozaik karyotipli bireylerin ise \%32'sinde sekonder seks karakter gelişiminin olduğu tahmin edilmektedir (Pasquino et al., 1997).

TS'lu bireylerde meydana gelen kromozomal anomalilerin fenotip ve fertilite üzerinde çeşitli etkileri bulunmaktadır. Örneğin Xp veya Xq delesyonlarının olduğu her iki durumda farklı anomaliler meydana gelir. Xq13-28 arasında ovaryen fonksiyonlar ile ilgili önemli genlerin bulunduğu belirtilmiştir (Mercer et al., 2013). Xq13-21'nin proksimal bölümündeki delesyonlar normal menstrual 
siklus ve fertilite ile ilişkilendirilmektedir. Xq23-28'nin distal bölgesindeki delesyonların ise prematür ovaryen yetmezlik ile ilişkili olduğu belirtilmiştir (Mercer et al., 2013). Xp delesyonlarında ise genellikle ovaryen fonksiyonların normal olduğu ve fertilitenin de görülebildiği bildirilmiştir (Adachi, Tachibana, Asakura, Muroya, \& Ogata, 2000; Kara ve ark., 2011). TS'lu bireylerin yaklaşık \%6'sında ise halka X kromozom anomalisinin görüldügü bildirilmiştir (Sybert, 2004). Bu bireylerde seksüel olgunluk ve spontan menarş meydana gelmeyebilir. Ancak hormon replasman tedavileri fertilitenin kazanılmasında etkili olabilmektedir (Blumenthal \& Allanson, 1997). İzokromozom durumunun ise çeşitlilik gösterdiği ve TS'nun diğer türlerine göre genellikle daha az şiddetli olduğu belirtilmektedir (Elsheiken, Dunger, Conway, \& Wass, 2002). Ancak bu anomaliye sahip TS'lu bireylerde de amenore, gonadal disgenezi, gelişmemiş uterus ve kısa vajina gibi üreme fonksiyonlarında sorunlar meydana gelebilmektedir (Llanes \& Uyking-Naranjo, 2019).

Y kromozom mozaisizmi her 10.000 canlı doğumda bir görülen bir durumdur. Bu bireyler normal bir erkek fenotipinde olabileceği gibi Turner Sendromunun diğer fenotip özelliklerini de taşıyabilirler (Costa et al., 1998). Bu bireyler çoğunlukla maskülen dış genital yapılara sahiptirler. Ayrıca bu bireylerde gonadoblastoma ve diğer gonadal tümörlerin gelişme riskinin de yüksek olduğu belirtilmiştir (Al Alwan et al., 2014). Y kromozomu üzerinde cinsel farklılaşmayı regüle eden çok fazla miktarda gen olduğu için bu vakalarda androjen düzeyleri farklılık göstermektedir. Bu durum sekonder seks karakterlerinin gelişimi ve fertilite açısından önem taşımaktadır (Radtke et al., 2014). Y kromozomu bulunan dişilerde, anormal gelişim gösteren stroma hücreleri ve granüloza/sertoli hücreleri androjen hormonu üreteceği için virilizasyon riskinin daha yüksek olduğu ifade edilmiştir (Reynaud et al., 2004). Y kromozom mozaisizmi gösteren olgularda infertilitenin sık görüldüğü bildirilmiştir (Newberg et al., 1998).

Hipogonadizm durumu ile seksüel fonksiyonlar arasında da bir ilişkinin bulunduğu düşünülmektedir. TS'lu bireylerin sadece \%50'sinde seksüel aktivitenin görüldüğü ve daha çok seksüel uyarılma sorunları geliştiği tespit edilmiştir (Ros, Alobid, Balasch, Mullol, \& Castelo-Branco, 2013). Bunun yanı sıra tatmin olma, lubrikasyon ve orgazm olma ile ilgili sorunlarında görülebildiği bildirilmiştir (Ros et al., 2013). Ancak bu sorunlar ile ilgili sağlkklı bireyler ile TS'lu bireyler arasında anlamlı bir düzeyde farklılık olmadığı belirtilmiştir. Seksüel fonksiyonlarda azalma ile sendromun spesifik hormonal veya genetik özellikleri arasında da anlamlı bir ilişki bulunamamıştır (Ros et al. 2013). Yapılan başka bir çalışmada ise TS'lu bireylerde seksüel fonksiyonları etkileyebileceği düşünülen; yaş, perdeli boyun gibi fenotip özellikleri, stigma durumu, testosteron seviyeleri, östrojen kullanımı, ergenlik yaşı ve işitme kaybı gibi faktörler incelenmiştir. Bu faktörler ile seksüel işlev bozukluğu arasında ilişki bulunamamıştır. Sadece boy uzunluğu ve eğitim seviyesinin partner ilişkilerini ve seksüel fonksiyonları etkilediği görülmüştür (Sheaffer, Lange, \& Bondy, 2008). 
Özetle, over fonksiyonları ve fertilite durumu 46,XX kromozom içeren hücre sayısı ile ilişkilidir. Çünkü mozaik 45,X'li bireylerin overlerinde bulunan folikül hücrelerinin, 46,XX kromozom içeren az sayıdaki germ hücrelerinden kaynaklandığı belirtilmektedir. $\mathrm{Bu}$ sebeple fonksiyonel over dokusunun bulunma olasılığının 46,XX kromozomlu germ hücrelerinin varlığı ile bağlantılı olduğu ve fertilite durumunun da 45,X/46,XX mozaisizmi bulunan bireylerde daha olas1 olduğu tahmin edilmektedir (Balen, Harris, Chambers, \& Picton, 2010). Ancak fonksiyonel over dokusu bulunsa bile ilerleyen zamanlarda prematür overyen yetmezliğin gelişebildiği ve ayrıca, fertilize olan zigotta ise kromozomal anomali gelişme riskinin genel populasyona göre daha yüksek olduğu belirtilmiştir (Blair et al., 2001).

\section{Turner Sendromunda Yardımeı Üreme Tekniklerinin Kullanımı ve Gebelik}

Turner Sendromunda spontan gebelik prevalansı \%4,8-7,6 arasında değişmektedir. Ancak spontan gebeliklerden sonra abortus riskinin yüksek olduğu ifade edilmiştir (Gravholt et al., 2017). TS'da spontan gebelik prevalansı ve gebelik sonuçlarını belirlemek için Fransa'da yapılan bir çalışmada; 480 TS'lu kadından sadece \%19,8'inde spontan menarşın meydana geldiği ve spontan gebelik prevalansının ise \%5,6 olduğu saptanmıştır. Gebeliklerden \%57,7'sinin terme kadar devam ettiği, \%30,8'inde abortus geliştiği, \%5,8'inde tıbbi müdahale gerektiği, \%3,8'inde yasal kürtaj yapıldığı ve \%1,9'unda intrauterin fetal ölüm meydana geldiği belirtilmiştir. Ayrıca sezaryen oranının da genel popülasyonla kıyasla daha yüksek olduğu tespit edilmiştir (\%46,7'ye karşın \%21) (Bernard et al., 2016). TS'lu kadınlarda spontan gebelik prevalansı ile ilgili başka ülkelerde yapılan çalışmalarda; spontan gebelik prevalansının Danimarka'da \%7,6, İsveç'te \%4,8 ve Amerika'da ise \%1,8 olduğu tespit edilmiştir (Birkebaek, Cruger, Hansen, Nielsen, \& Brunn-Petersen, 2002; Bryman et al., 2011; Hadnott, Gould, Gharib, \& Bondy, 2011). Amerika'da yapılan çalışmada; TS'lu kadınlarda oosit donasyonu ve yardımcı üreme teknikleri ile meydana gelen gebelik oranlarının spontan gebelik oranları ile benzer olduğu görülmüsstür (Hadnott et al., 2011). Türkiye'de 22 mozaik TS'lu kadın ile yapılan bir çalışmada; implantasyon oranının $\% 3,7$ ve klinik gebelik oranının \%8,6 olduğu görülmüştür. Ancak kadınlardan \%5,7'sinin eve bebekleri ile dönebildiği belirtilmiştir (Doğer et al. 2015).

Turner Sendromlu kadınlarda erken yaşlardan itibaren oosit kaybında hızla artış olması kendi oositleri ile gebelik şanslarını azaltmaktadır. Ayrıca yaşın ilerlemesi ile in vitro fertilizasyon (IVF) tedavilerinde başarı oranları da düşmektedir. Bu sebeple TS'lu kadınlara mümkün olduğu kadar erken dönemlerde üremeye yardımcı tedaviler sunulması gerektiği ve bu konuda danışmanlık vermenin önemli olduğu vurgulanmaktadır (Gravholt et al., 2017). Üremeye yardımcı tedaviler ile TS'lu kadınların gebe kalabilmesi mümkündür. Bu doğrultuda ergenlik döneminden sonra over fonksiyonları devam eden kadınlarda IVF tedavisi bir seçenek olabilir. Ancak overlerdeki azalmış oosit sayısı nedeniyle IVF sonucunda gebelik oranlarının düşük olacağı tahmin edilmektedir (Foudila, Söderström 
Antilla, \& Hovatta, 1999; Bodri et al., 2006). Ayrıca Turner Sendromlu birçok kız çocuğunun overlerinde foliküller bulunması sebebi ile fertilitenin korunabileceği ifade edilmektedir (Borgström et al., 2009). Bu sebeple, kontrollü ovaryen hiperstimülasyonundan sonra oosit dondurmanın, genç mozaik Turner Sendromlu kadınlarda ilerisi için olası bir doğurganlık koruma seçeneği olabileceği düşünülmektedir (Gravholt et al., 2017). Şu ana kadar 14-28 yaş arasındaki TS'lu kadınlarda 8-13 oosit dondurma işlemi rapor edilmiştir. Ancak bu yöntemle gebelik oluşumu henüz rapor edilmemiştir (El Shawarby, Sharif, Conway, Serhal, \& Davies, 2010; Oktay, Rodriques-Wallberg, \& Sahin, 2010).

Turner Sendromlu kadınların büyük çoğunluğunda ovaryen yetmezlik mevcut olduğu için, bu kadınlarda yardımcı üreme tedavilerinde oosit bağışı ve IVF tedavisinin önemli bir tedavi seçeneği olabileceği belirtilmektedir (Gravholt et al., 2017). Oosit bağışı ile IVF tedavisi yapılan 23 TS'lu kadının dâhil edildiği retrospektif bir çalışmada, taze ve dondurulmuş embriyoların kullanıldığı 49 oosit bağışı döngüsü değerlendirilmiştir. Taze döngülerde, embriyo transferi başına implantasyon oranının $\% 17,1$, gebelik oranının $\% 31,1$, klinik gebelik oranının ise $\% 24,4$ olduğu belirtilmiştir. Donmuş embriyo kullanımında ise implantasyon oranının \%18,2, gebelik oranının \%40 ve klinik gebelik oranının ise \%20 olduğu görülmüştür. 23 TS'lu kadından 10'unda gebeliklerin canlı doğumla sonuçlandığı ve 5 gebede gebeliğe bağlı hipertansiyon gibi komplikasyonların geliştiği bildirilmiştir (Alvaro Mercadal, Imbert, Demeestere, Englert, \& Delbaere, 2011). Oosit bağışı ile ilgili 21 TS’lu kadının dâhil edildiği başka bir çalışmada ise; implantasyon oranının \%22, klinik gebelik oranının $\% 40$ ve devam eden gebelik oranının ise \%30 olduğu saptanmıştır. Bu çalışmada da TS'lu kadınlarda gebelik sırasında hipertansf bozukluğun geliştiği rapor edilmiştir (Bodri et al., 2006). Oosit bağışı ile tedavi edilen 18 TS'lu kadın ile yapılan başka bir çalışmada; taze embriyo transferi başına implantasyon oranının \%30, klinik gebelik oranının ise \%46 olduğu görülmüştür. Bu oranların genel olarak primer ovaryen yetmezliği olan oosit alıcılarındaki oranlar ile benzer olduğu ifade edilmiştir. Dondurulmuş embriyo transferinde ise implantasyon oranının \%19 ve klinik gebelik oranının \%28 olduğu tespit edilmiştir (Foudila et al., 1999). Turner Sendromlu kadınlarda oosit bağışından sonra implantasyon ve gebelik oranlarının yüksek olduğu, ancak kardiyovasküler ve diğer komplikasyonların gelişme riskinin yüksek olduğu belirtilmiştir (Foudila et al., 1999). Bu sebeple gebelik öncesinde ve gebelik sırasında dikkatli bir değerlendirme yapılması gerektiği vurgulanmıştır (Foudila et al., 1999). Turner Sendromlu 29 kadın ile yapılan başka bir çalışmada ise; döngü başına klinik gebelik oranının \% 41,2, embriyo başına implantasyon oranının \%17,1 ve tedavi döngüsü başına eve bebek ile dönme oranının \%19,1 olduğu belirtilmiştir. Ayrıca taze embriyo transferi sonucunda implantasyon (\%20,3'e karşın \%8,2) ve klinik gebelik (\%48'e karşın \%22,2) oranlarının daha yüksek olduğu saptanmıştır (Khastgir et al., 1997). Genel abortus oranının yüksek olduğu (\%50) vurgulanmıştır (Khastgir et al., 1997). Oosit bağışı TS'lu kadınlarda üremeye yardımcı tedaviler için bir seçenek olarak görülse de, klinik gebelik ve canlı doğum oranlarının normal popülasyona kıyasla 
oldukça düşük olduğu ve anormal uterus, otoimmün mekanizmalar ve hipoöstrojenizme bağl1 olarak abortus riskinin de yüksek olduğu ifade edilmektedir (Gravholt et al., 2017).

\section{İnfertilite Hemşirelerinin Rol ve Sorumlulukları ve Turner Sendromlu Bireylere Hemşirelik Yaklaşımı}

Multidisipliner bir ekip içinde yer alan infertilite hemşiresi bireyleri değerlendirme, tanı ve tedavi süreci ile ilgili bilgi verme, tedavi prosedürlerine yönelik eğitim ve danışmanlık hizmeti verme gibi rollere sahiptir. Ayrıca komplikasyonları gözlemleme, hastanın hakları savunma, araştırma yapma ve ekip içerisinde iletişim ve işleyişi sağlama gibi birçok sorumluluğu bulunmaktadır (Güngör ve Kızllkaya-Beji, 2015; Kavlak, 2015).

İnfertil bireyler fertilite probleminin yanı sıra psikolojik açıdan da ciddi ölçüde sıkıntılar yaşamaktadırlar. $\mathrm{Bu}$ süreçte bireylerin stresle baş edebilmesine yardımcı olmak, sosyal izolasyonu önleyerek psikolojik yükünü hafifletmek, anksiyete ve depresyon gelişimini önlemek veya psikolojik semptom düzeylerini azaltmak için bireylere özel danışmanlık hizmeti sunmak infertilite alanında çalışan hemşirelerin en önemli sorumluluklarından biridir (Güngör ve Kızılkaya-Beji, 2015). Hemşireler, doğurganlık tedavisi gören kadınlarla/çiftlerle sürekli etkileşim halindedirler. $\mathrm{Bu}$ doğrultuda uyum sorunlarını öngörmede, tanımlamada ve gerekli desteği sağlamada hemşireler önemli bir rol oynamaktadırlar (Stevenson, Hershberger, \& Bergh, 2016). Üremeye yardımcı tedaviler, aile kurmak isteyen birçok kadın/çift için umut sağlamaktadır. Ancak infertilite tanı ve tedavi süreci karmaş1k olabilir. Bu sebeple infertilite hemşirelerinin infertilite tanı ve tedavi süreci boyunca kanıta dayalı eğitim ve destek sağlaması gerekmektedir (Stevenson et al., 2016). Çünkü veriler süreçteki her adımın kadın/çift tarafından önemli olarak algılandığını ve gelecekteki kararları da etkileyebileceğini düşündürmektedir (Williams, Green, \& Roberts, 2010).

Turner Sendromuna sahip kadınlar sendromun türüne bağlı olarak fiziksel ve/veya mental birçok sorun ile karşılaşmaktadırlar. Özellikle bu bireyler, ovaryen fonksiyonlardaki yetersizlik/yetmezlik nedeniyle fertilitelerinin azalması ya da infertil olma durumu sebebiyle büyük kaygılar yaşamaktadırlar (Sutton et al., 2005; Sandberg et al., 2019). Üremeye yardımcı tedavi uygulamalarındaki gelişmelere rağmen bu kadınlarda spontan gebelik ihtimalinin düşük olması ve gebeliğin getirebileceği sağlığa yönelik riskler TS'lu kadınlar için büyük bir endişe kaynağıdır (Bernard et al., 2016; Grynberg et al., 2016). Turner Sendromlu kadınlarda genç yaşlardan itibaren oosit sayısı ve spontan gebe kalma şansları hızla azaldığı için erken dönemde üremeye yardımcı tedaviler ile ilgili danışmanlık hizmetlerinin sağlanması hayati önem taşımaktadır (Gravholt et al., 2017). Fertilitenin korunmasına veya gelecekte gebeliğin sağlanmasına yönelik verilecek danışmanlık hizmetine tanı anında başlanması gerektiği belirtilmektedir. TS'da infertilite tedavisi ve gebelik süreci komplikasyonlu olabilir. Bu durum kadınlarda keder ve sıkıntıya yol açabilir ve bu sebeple olası riskler ve sonuçlara karşı hazırlıklı olunması gerekmektedir. Bu sebeple profesyonel bir ekip ile 
birlikte, çocuk sahibi olma ile ilgili çeşitli seçenekler hakkında bilgi verilmesi ve oosit bağışı ile gebeliğin ve gebeliğin getireceği olası risklerin anlaşılır bir dil ile açıklanması gerekmektedir. Ayrıca evlat edinmenin annelik arzularını yerine getirme için başka bir seçenek olabileceği de açıklanabilir (Gravholt et al., 2017).

Genel olarak, fertilite sorunları olan kadınlar için terapötik müdahaleler, kendi kimliklerinin farkına varabilmelerini, eşleri ile olan ilişkilerini güçlendirebilmelerini ve infertilite ile sağlıklı bir şekilde başa çıkabilmelerini sağlamaktadır (Boivin, 2003). Farklı ihtiyaçlarla ilgili olarak, bireysel veya çift psikodinamik tedavi, gevşeme teknikleri ve stres azaltma, bilişsel-davranışçı terapiler, çift cinsiyet terapisi ve destek grupları olmak üzere farklı müdahale teknikleri bulunmaktadır (Turan ve Aksoy-Poyraz, 2015). Bu müdahale yöntemleri arasından en uygun olanını belirlemek, risk durumlarının değerlendirilmesi açısından önemlidir. Bazı durumlarda basit bir destekleyici müdahale yeterli olsa da, diğerleri için daha spesifik psikolojik tedavi yöntemi gerekebilir. Psikolojik danışmanlık ve terapötik müdahaleler, özellikle tekrarlanan başarısız tedaviler durumunda mevcut durumun yeniden yorumlanmasını kolaylaştırabilir. Ayrıca infertil çiftin biyolojik olarak çocuk sahibi olamama ile gerçekçi bir şekilde başa çıkabilmesinde de faydalı olabilir (Hynes, Callan, Terry, \& Gallois, 1992).

Cinsel ilişkinin yalnızlık veya olumsuz benlik algısı gibi düşünceleri iyileştirmeye yardımcı olduğu belirtilmektedir (Dolega, Jez, \& Irzyniec, 2014). Ancak, Turner Sendromlu kadınların cinsel hayatlarında yaşıtlarından daha az aktif oldukları bildirilmiştir (Ros et al., 2013). Bu nedenle, cinsel yaşamdaki sorunların hassasiyet ve dikkatle değerlendirilmesi gerekmektedir. TS'lu kadınlarda cinsel yaşamın, psikomedikal yardım gerektiren önemli bir alan olabileceği ve yaşam kalitesinin bir göstergesi olabileceği ifade edilmektedir. Aktif bir cinsel yaşamın TS'lu kadınların, psikolojik olarak, kendilerini kadınsı hissetmelerini sağlayabileceği ve onları olumsuz benlik saygısı ve yalnızlık düşüncelerine karşı koruyabileceği belirtilmektedir (Dolega et al., 2014). İnfertiletede cinsel sorunların tedavisinde uygun müdahalenin belirlenebilmesi için öncelikle kadın ve erkeğin bireysel özellikleri göz önünde bulundurulmalıdır. Ayrıca cinsel sorunlara yönelik müdahalelerde, hatalı davranışları düzeltmek ve bireylerin kaygılarını azaltma amacıyla belli bir süre cinsel perhiz uygulanmaktadır. Terapi sürecinde duyumsal keşif ile çiftlerde performans anksiyetesinin azaltılması sağlanmaktadır (Çeri, Yılmaz, ve Soykan, 2008). Bu sürecin ilk adımında öncelikle cinsel birleşme ve orgazm olmadan birbirini okşama ve birbirlerinin bedenlerini keşfetme ve iletişim ile çiftlerin birbirlerinin farkına varması sağlanmaktadır. Daha sonraki aşamada ise sürekli ve orgazma neden olmadan cinsel organların okşanması yer almaktadır. Burada amaç, cinselliğin mekanik bir eylem olmadığı, gerçekte duyguların ve bedensel hazzın paylaşıldığı bir eylem olduğunun farkına varılmasını sağlamaktır. Belirlenen uygun müdahaledeki tekniklerin anlaşılır ve ayrıntılı bir biçimde açıklanması ve her oturumunda aşamalı olarak ev ödevleri verilmesi ve terapilerin yoğunluğunun azdan artan yoğunluğa kadar kademeli olarak arttırılması gerekmektedir (Çeri ve ark., 2008). 
Özetle, İnfertilite tedavisi gören kadınlar için psikolojik semptomların iyileştirilmesinin, gebelik sonuçları üzerinde kesin olumlu bir etkisi yoktur, ancak hemşirelerin bu stresli süreci anlamaları gerekmektedir. Çünkü hemşirelerin kadınların psikolojik durumlarını ve stresle baş etme stratejilerini anlaması, kadın sağlığını geliştirmeye önemli bir katkı sağlar (Rosenstein, 2017).

\section{SONUÇ ve ÖNERILER}

Turner sendromu, üreme sistemi ve diğer sistemler üzerindeki etkileri düşünüldüğünde dikkatli bir şekilde ele alınması gereken önemli bir kromozomal anomalidir. Sendromun tipine bağlı olarak spontan menarş ve gebelik meydana gelebileceği gibi hormon replasmanı ve/veya yardımcı üreme teknikleri ile de fertilite sağlanabilmektedir. Ancak mozaisizm bulunan olgularda bile zaman içinde sekonder amenore veya erken menopoz gelişebilmektedir. Aynı şekilde bu olgularda canlı doğum oranlarının da az olduğu ve kromozomal anomalili bir zigot oluşma ihtimalinin de yüksek olduğu belirtilmektedir.

Fertilitenin olmaması veya fertilitede azalmaya neden olması ve dış görünüşteki farklılıklar nedeniyle Turner sendromlu bireylerde psikososyal ve psikoseksüel sıkıntılar gelişebilmektedir. Bireyler dış görünüşleri veya fertilite durumları ile ilgili düşük benlik saygısı, seksüel işlevde bozulma ve partnerleri ile ilişkilerinde sorunlar yaşayabilmektedirler. Bazı mozaisizmli olgularda hormon replasman tedavileri ile bireylerin sekonder seks karakterlerinin gelişimi sağlanabilmekte ve over fonksiyonları da iyileştirilebilmektedir. Ayrıca yardımcı üreme tekniklerinden de gebeliğin sağlanmasında yararlanılmaktadır. Bu sebeple gerekli durumlarda prenatal karyotip analizlerinin yapılması ve doğum sonunda karyotip analizinin tekrarlanması önem taşımaktadır. Ayrıca doğum sonu dönemde bebeğe dikkatli bir fizik muayene yapılması, şüpheli durumlarda USG ile uterus ve overler başta olmak üzere iç organlar anomaliler yönünden incelenmesi ve gerekli görüldüğünde karyotip analizinin yapılması gerekmektedir.

Hemşireler prenatal tanılama, doğum sonu bebek izlemi ve fizik muayenenin önemi konusunda bireylerin, ailelerin, kendilerinin ve meslektaşlarının farkındalığını arttırmalıdır. Ayrıca infertilite hemşireleri, yardımcı üreme teknikleri ile tedavi gören TS'lu bireylerin bilgi ihtiyaçlarını gidermeli ve gerekli psikolojik ve psikoseksüel desteğin verildiği kaynaklara bireyi yönlendirmelidir. Ailelerin ve bireylerin eğitilmesi, psikolojik destek sistemlerinin kullanımı, replasman tedavileri ve yardımcı üreme teknikleri ile TS'lu bireylerin psikososyal ve psikoseksüel açıdan daha sağliklı bir yaşam sürmeleri sağlanabilir. 


\section{KAYNAKLAR}

Adachi, M., Tachibana, K., Asakura, Y., Muroya, K., \& Ogata, T. (2000). Del(X)(p21.1) in a mother and two daughters: genotype-phenotype correlation of Turner features. Human Genetics, 106, 306-10. doi: 10.1007/s004390051042

Al Alwan, I., Khadora, M., Amir, I., Nasret, G., Omair, A., Brown, L., et al. (2014). Turner Syndrome Genotype and phenotype and their effect on presenting features and timing of Diagnosis. International Journal of Health Sciences, Qassim University, 8 (2), 195-202. doi: $10.12816 / 0006086$

Alvaro Mercadal, B., Imbert, R., Demeestere, I., Englert, Y., \& Delbaere, A. (2011). Pregnancy outcome after oocyte donation in patients with Turner's syndrome and partial X monosomy. Human Reproduction, 26 (8), 2061-8. doi: 10.1093/humrep/der166

Balen, A. H., Harris, S. E., Chambers, E. L., \& Picton, H. M. (2010). Conservation of fertility and oocyte genetics in a young woman with mosaic Turner syndrome. An International Journal of Obstetrics and Gynaecology, 117 (2), 238-42. doi: 10.1111/j.1471-0528.2009.02423.x

Bernard, V., Donadille, B., Zenaty, D., Courtillot, C., Salenave, S., Brac de la Perriere, A., et al. (2016). Spontaneous fertility and pregnancy outcomes amongst 480 women with Turner syndrome. Human Reproduction, 31 (4), 782-8. doi: 10.1093/humrep/dew012

Birkebaek, N. H., Cruger, D., Hansen, J., Nielsen, J., \& Bruun-Petersen, G. (2002). Fertility and pregnancy outcome in Danish women with Turner syndrome. Clinical Genetics, 61 (1), 35-9. doi: 10.1034/j.1399-0004.2002.610107.x

Blair, J., Tolmie, J., Hollman, A. S., \& Donaldson, M. D. (2001). Phenotype, ovarian function, and growth in patients with 45,X/47,XXX Turner mosaicism: implications for prenatal counseling and estrogen therapy at puberty. The Journal of Pediatrics, 139 (5), 724-28. doi: $10.1067 / \mathrm{mpd} .2001 .118571$

Blumenthal, A. L., \& Allanson, J. E. (1997). Turner syndrome in a mother and daughter: r(X) and fertility. Clinical Genetics, 52 (3), 187-91. doi: 10.1111/j.1399-0004.1997.tb02543.x

Bodri, D., Vernaeve, V., Figueras, F., Vidal, R., Guillén, J. J., \& Coll, O. (2006). Oocyte donation in patients with Turner's syndrome: a successful technique but with an accompanying high risk of hypertensive disorders during pregnancy. Human Reproduction, 21 (3), 829-32. doi: 10.1093/humrep/dei396

Boivin, J. (2003). A review of psychosocial interventions in infertility. Social Science \& Medicine, 57 (12), 2325-41. doi: 10.1016/S0277-9536(03)00138-2 
Bondy, C. A. (2007). Care of girls and women with Turner syndrome: a guideline of the Turner Syndrome Study Group. The Journal of Clinical Endocrinology \& Metabolism, 92 (1), 10-25. doi: $10.1210 /$ jc.2006-1374

Borgström, B., Hreinsson, J., Rasmussen, C., Sheikhi, M., Fried, G., Keros, V., et al. (2009). Fertility preservation in girls with turner syndrome: prognostic signs of the presence of ovarian follicles. The Journal of Clinical Endocrinology \& Metabolism, 94 (1), 74-80. doi: 10.1210/jc.2008-0708

Broer, S. L., Broekmans, F. J., Laven, J. S., \& Fauser, B. C. (2014). Anti-Mullerian hormone: ovarian reserve testing and its potential clinical implications. Human Reproduction Update, 20 (5), 688-701. doi: 10.1093/humupd/dmu020

Bryman, I., Sylven, L., Berntorp, K., Innala, E., Bergstrom, I., Hanson, C., et al. (2011). Pregnancy rate and outcome in Swedish women with Turner syndrome. Fertility and Sterility, 95 (8), 2507-10. doi: 10.1016/j.fertnstert.2010.12.039

Cadoret, F., Parinaud, J., Bettiol, C., Pienkowski, C., Letur, H., Ohl, J., et al. (2018). Pregnancy outcome in Turner syndrome: A French multi-center study after the 2009 guidelines. European Journal of Obstetrics \& Gynecology and Reproductive Biology, 229, 20-25. doi: 10.1016/j.ejogrb.2018.08.005

Costa, T., Lambert, M., Teshima, I., Ray, P. N., Richer, C. L., \& Dallaire, L. (1998). Monozygotic twins with 45,X/46,XY mosaicism discordant for phenotypic sex. American Journal of Medical Genetics, 75 (1), 40-4. doi: 10.1002/(SICI)1096-8628(19980106)75:1<40::AIDAJMG9>3.0.CO;2-U

Çeri, Ö., Yılmaz, A. ve Soykan, A. (2008). Cinsel işlev bozuklukları. Türkiye Klinikleri Psikiyatri Özel Konular, 1 (2), 71-8.

Doğer, E., Çakıroğlu, Y., Ceylan, Y., Ulak, E., Özdamar, Ö., \& Çalışkan, E. (2015). Reproductive and obstetric outcomes in mosaic Turner's Syndrome: a cross-sectional study and review of the literature. Reproductive Biology and Endocrinology, 13, 59. doi: 10.1186/s12958-015-0055-7

Dolega, Z., Jez, W., \& Irzyniec, T. (2014). The cohort effect in studies related to differences in psychosocial functioning of women with Turner syndrome. Endokrynologia Polska, 65 (4), 287-94.

El-Shawarby, S.A., Sharif, F., Conway, G., Serhal, P., \& Davies, M. (2010). Oocyte cryopreservation after controlled ovarian hyperstimulation in mosaic Turner syndrome: another fertility preservation option in a dedicated UK clinic. An International Journal of Obstetrics and Gynaecology, 117 (2), 234-7. doi: 10.1111/j.1471-0528.2009.02422.x 
Elsheikh, M., Dunger, D. B., Conway, G. S., \& Wass, J. A. (2002). Turner's syndrome in adulthood. Endocrine Reviews, 23 (1), 120-40. doi: 10.1210/edrv.23.1.0457

Ford, C. E., Jones, K. W., Polani, P. E., De Almeida, J. C., \& Briggs, J. H. (1959). A sex-chromosome anomaly in a case of gonadal dysgenesis (Turner's syndrome). Lancet, 1 (7075):711-713. doi: $10.1016 / \mathrm{s} 0140-6736(59) 91893-8$

Foudila, T., Söderström-Anttila, V., \& Hovatta, O. (1999). Turner's syndrome and pregnancies after oocyte donation. Human Reproduction, 14 (2), 532-5. doi: 10.1093/humrep/14.2.532

Gil, M. M., Quezada, M. S., Revello, R., Akolekar, R., \& Nicolaides, K. H. (2015). Analysis of cellfree DNA in maternal blood in screening for fetal aneuploidies: updated meta-analysis. Ultrasound in Obstetrics \& Gynecology, 45 (3), 249-266. doi: 10.1002/uog.14791

Glass, I. A., Rauen, K. A., Chen, E., Parkes, J., Alberston, D. G., Pinkel, D., et al. (2006). Ring chromosome 15: characterization by array CGH. Human Genetics, 118 (5), 611-617. doi: 10.1007/s00439-005-0030-z

Güngör, İ., \& Kızılkaya-Beji, N. (2015). İnfertilite hemşirelerinin gelişen rolleri ve sertifikasyon gereksinimi. Florence Nightingale Hemşirelik Dergisi, 23 (2), 152-9.

Gravholt, C. H. (2014). Epidemiological, endocrine and metabolic features in Turner syndrome. European Journal of Endocrinology, 151 (6), 657-87. doi: 10.1530/eje.0.1510657

Gravholt, C. H., Andersen, N. H., Conway, G. S., Dekkers, O. M., Geffner, M. E., Klein, K. O., et al. (2017). Clinical practice guidelines for the care of girls and women with Turner syndrome: proceedings from the 2016 Cincinnati International Turner Syndrome Meeting. European Journal of Endocrinology, 177 (3), G1-70.

Grynberg, M., Bidet, M., Benard, J., Poulain, M., Sonigo, C., Cedrin-Durnerin, I., et al. (2016). Fertility preservation in Turner syndrome. Fertility and Sterility, 105 (1), 13-19. doi: 10.1016/j.fertnstert.2015.11.042

Gunther, D. F., Eugster, E., Zagar, A. J., Bryant, C. G., Davenport, M. L., \& Quigley, C. A. (2004). Ascertainment bias in Turner syndrome: new insights from girls who were diagnosed incidentally in prenatal life. Pediatrics, 114 (3), 640-644. doi: 10.1542/peds.2003-1122-L

Hadnott, T. N., Gould, H. N., Gharib, A. M., \& Bondy, C. A. (2011). Outcomes of spontaneous and assisted pregnancies in Turner syndrome: The U.S. National Institutes of Health experience. Fertility and Sterility, 95 (7), 2251-6. doi: 10.1016/j.fertnstert.2011.03.085

Hagen, C. P., Aksglaede, L., Sorensen, K., Main, K. M., Boas, M., Cleemann, L., et al. (2010). Serum levels of anti-Mullerian hormone as a marker of ovarian function in 926 healthy females from 
birth to adulthood and in 172 Turner syndrome patients. The Journal of Clinical Endocrinology \& Metabolism, 95 (11), 5003-10.

Hagen, C. P., Main, K. M., Kjaergaard, S., \& Juul, A. (2010). FSH, LH, inhibin B and estradiol levels in Turner syndrome depend on age and karyotype: longitudinal study of 70 Turner girls with or without spontaneous puberty. Human Reproduction, 25 (12), 3134-41. doi: 10.1093/humrep/deq291

Harel, T., Pehlivan, D., Caskey, C. T., \& Iupski, J. R. (2015). Mendelian, Non-Mendelian, Multigenic Inheritance, and Epigenetics. $5^{\text {th }}$ ed. p. 3-27.

Hockner, M., Utermann, B., Erdel, M., Fauth, C., Utermann, G., \& Kotzot, D. (2008). Molecular characterization of a de novo ring chromosome 6 in a growth retarded but otherwise healthy woman. American Journal of Medical Genetics Part A, 146A (7), 925-929. doi: 10.1002/ajmg.a.32251

Hovatta, O. (1999). Pregnancies in women with Turner's syndrome. Annals of Medicine, 31 (2), 10610.

Hynes, G. J., Callan, V. J., Terry, D. J., \& Gallois, C. (1992). The psychological well-being of infertile women after a failed IVF attempt: the effects of coping. British Journal of Medical Psychology, 65 ( Pt 3), 269-78. doi: 10.1111/j.2044-8341.1992.tb01707.x

Kara, N., Ökten, G., Tural, Ş., Artan, S., Sezer, Ö., \& Koçak, İ. (2011). Mozaik 45,X/46,X,der(X) karyotipi saptanan primer amenoreli bir olguda Trizomi Xq ve delesyon Xp fenotipi. Turkiye Klinikleri Tip Bilimleri Dergisi, 31 (3), 706-11. doi: 10.5336/medsci.2009-13378

Kavlak, O. (2015). İnfertilite. In A. Şirin, O. Kavlak (Eds). Kadın Sağlığı. (2. Baskı). İstanbul: Nobel Tip Kitabevleri; 206-15.

Kelsey, T. W., Wright, P., Nelson, S. M., Anderson, R. A., \& Wallace, W. H. (2011). A validated model of serum anti-mullerian hormone from conception to menopause. PloS One, 6 (7), e22024. doi: 10.1371/journal.pone.0022024

Khastgir, G., Abdalla, H., Thomas, A., Korea, L., Latarche, L., \& Studd, J. (1997). Oocyte donation in Turner's syndrome: an analysis of the factors affecting the outcome. Human Reproduction, 12 (2), 279-85. doi: 10.1093/humrep/12.2.279

Llanes, M. R. V., \& Uyking-Naranjo, M. (2019). Isochromosome Mosaic Turner Syndrome: A case report. Journal of the ASEAN Federation of Endocrine Societies, 34 (2), 220-5. doi: 10.15605/jafes.034.02.15

Mercer, C. L., Lachlan, K., Karcanias, A., Affara, N., Huang, S., Jacobs, P. A., et al. (2013). Detailed clinical and molecular study of 20 females with $\mathrm{Xq}$ deletions with special reference to 
menstruation and fertility. European Journal of Medical Genetics, 56 (1), 1-6. doi: 10.1016/j.ejmg.2012.08.012

Modi, D. N., Sane, S., \& Bhartiya, D. (2003). Accelerated germ cell apoptosis in sex chromosome aneuploid fetal human gonads. Molecular Human Reproduction, 9 (4), 219-225. doi: 10.1093/molehr/gag031

Newberg, M. T., Francisco, R. G., Pang, M. G., Brugo, S., Doncel, G. F., Acosta, A. A., et al. (1998). Cytogenetics of somatic cells and sperm from a 46,XY/45,X mosaic male with moderate oligoasthenoteratozoospermia. Fertility and Sterility, 69 (1), 146-8. doi: 10.1016/s00150282(97)00443-3

Oktay, K., Rodriguez-Wallberg, K. A., \& Sahin, G. (2010). Fertility preservation by ovarian stimulation and oocyte cryopreservation in a 14-year-old adolescent with Turner syndrome mosaicism and impending premature ovarian failure. Fertility and Sterility, 94 (2), 753.e15-9. doi: 10.1016/j.fertnstert.2010.01.044

Pasquino, A.M., Passeri, F., Pucarelli, I., Segni, M., \& Municchi, G. (1997). Spontaneous pubertal development in Turner's syndrome. Italian Study Group for Turner's Syndrome. The Journal of Clinical Endocrinology \& Metabolism, 82 (6), 1810-1813. doi: 10.1210/jcem.82.6.3970

Pinsker, J. E. (2012). Clinical review: Turner syndrome: updating the paradigm of clinical care. The Journal of Clinical Endocrinology \& Metabolism, 97 (6), E994-1003. doi: 10.1210/jc.20121245

Radtke, A. C., Sauder, C., Rehm, J. L., \& McKenna, P. H. (2014). Complexity in the Diagnosis and Management of 45,X Turner Syndrome Mosaicism. Urology, 84 (4), 919-921. doi: 10.1016/j.urology.2014.06.030

Reindollar, R. H. (2011). Turner syndrome: Contemporary thoughts and reproductive issues. Seminars in Reproductive Medicine, 29 (4), 342-352. doi: 10.1055/s-0031-1280919

Reynaud, K., Cortvrindt, R., Verlinde, F., De Schepper, J., Bourgain, C., \& Smitz, J. (2004). Number of ovarian follicles in human fetuses with the 45,X karyotype. Fertility and Sterility, 81 (4), 1112-1119. doi: 10.1016/j.fertnstert.2003.12.011

Ros, C., Alobid, I., Balasch, J., Mullol, J., \& Castelo-Branco, C. (2013). Turner's syndrome and other forms of congenital hypogonadism impair quality of life and sexual function. American Journal of Obstetrics and Gynecology, 208 (6), 484.e1-6. doi: 10.1016/j.ajog.2013.01.011

Rosenstein, T. (2017). An Analysis of the Mental Health, Coping Ability, and Related Nursing Interventions of Women Undergoing Infertility Treatment. Grace Peterson Nursing Research 
Colloquium; DePaul University; 1-2. Available from Erişim tarihi: 25.03.2020, https://via.library.depaul.edu/cgi/viewcontent.cgi?article=1144\&context=nursing-colloquium

Sadler, T. W. (2012). Gametogenesis: Conversion of Germ Celss into Male and Female Gametes. Langman's Medical Embryology. $12^{\text {th }}$ ed. Lippincott Williams \& Wilkins.

Saenger, P. (2008). Turner Syndrome. In M. Sperling (Ed). 3rd ed. Philadelphia: Saunders; p. 610661.

Sandberg, D. E., Singer, D., Bugajski, B., Gebremariam, A., Scerbak, T., Dooley Maley, K. L., et al. (2019). Research priorities of people living with Turner syndrome. American Journal of Medical Genetics Part C: Seminars in Medical Genetics, 181 (1), 43-51. doi: 10.1002/ajmg.c.31676

Schlessinger, D., Herrera, L., Crisponi, L., Mumm, S., Percesepe, A., Pellegrini, M., et al. (2002). Genes and translocations involved in POF. American Journal of Medical Genetics, 111 (3), 328-333. doi: 10.1002/ajmg.10565

Shankar, R. K., \& Backeljauw, P. F. (2018). Current best practice in the management of Turner syndrome. Therapeutic Advances in Endocrinology and Metabolism, 9 (1), 33-40. doi: $10.1177 / 2042018817746291$

Sheaffer, A. T., Lange, E., \& Bondy, C. A. (2008). Sexual function in women with Turner syndrome. Journal of Women's Health, 17 (1), 27-33. doi: 10.1089/jwh.2007.0488

Sodre, C. P., Guilherme, R. S., Meloni, V. F., Brunoni, D., Juliano, Y., Andrade, J. A., et al. (2010). Ring chromosome instability evaluation in six patients with autosomal rings. Genetics and Molecular Ressearch, 9 (1), 134-143. doi: 10.4238/vol9-1gmr707

Stevenson, E. L., Hershberger, P. E., \& Bergh, P. A. (2016). Evidence-Based Care for Couples With Infertility. Journal of Obstetric, Gynecologic \& Neonatal Nursing, 45 (1), 100-10. doi: 10.1016/j.jogn.2015.10.006

Stochholm, K., Juul, S., Juel, K., Naeraa, R. W., \& Gravholt, C. H. (2006). Prevalence, incidence, diagnostic delay, and mortality in Turner syndrome. The Journal of Clinical Endocrinology \& Metabolism, 91 (10), 3897-3902. doi: 10.1210/jc.2006-0558

Sutton, E. J., McInerney-Leo, A., Bondy, C. A., Gollust, S. E., King, D., \& Biesecker, B. (2005). Turner syndrome: Four challenges across the lifespan. American Journal of Medical Genetics Part A, 139A (2), 57-66. doi: 10.1002/ajmg.a.30911

Sybert, V. P. (2002). Phenotypic effects of mosaicism for a 47,XXX cell line in Turner syndrome. Journal of Medical Genetics, 39 (3), 217-20. doi: 10.1136/jmg.39.3.217 
Sybert, V. P., \& McCauley, E. (2004). Turner's syndrome. The New England Journal of Medicine, 351 (12), 1227-1238. doi: 10.1056/NEJMra030360

Turan, Ş., \& Aksoy-Poyraz, C. (2015). Günlük yaşam stresiyle baş etmek için kullanılan psikoterapi yöntemleri. Bilişsel Davranış̧̧ Psikoterapi ve Araştırmalar Dergisi, 3, 133-40.

Turner, H. H. (1938). A syndrome of infantilism, congenital webbed neck, and cubitus valgus. Endocrinology, 23, 566-574. doi: 10.1210/endo-23-5-566

Ullrich, O. (1930). Über typische Kombinationsbilder multipler Abartungen. Zeitschrift für Kinderheilkunde, 49 (3), 271-276. doi: 10.1007/BF02248090

Urbach, A., \& Benvenisty, N. (2009). Studying early lethality of 45,XO (Turner's syndrome) embryos using human embryonic stem cells. PloS One, 4 (1), e4175. doi: 10.1371/journal.pone.0004175

Visser, J.A., Hokken-Koelega, A.C., Zandwijken, G.R., Limacher, A., Ranke, M.B., \& Fluck, C.E. (2013). Anti-Mullerian hormone levels in girls and adolescents with Turner syndrome are related to karyotype, pubertal development and growth hormone treatment. Human Reproduction, 28 (7), 1899-1907. doi: 10.1093/humrep/det089

Williams, M., Green, L., \& Roberts, K. (2010). Exploring the needs and expectations of women presenting for hysterosalpingogram examination following a period of subfertility: A qualitative study. International Journal of Clinical Practice, 64 (12), 1653-60. doi: $10.1111 / \mathrm{j} .1742-1241.2010 .02431 . \mathrm{x}$

Zinn, A. R., Tonk, V. S., Chen, Z., Flejter, W. L., Gardner, H. A., Guerra, R., et al. (1998). Evidence for a Turner syndrome locus or loci at Xp11.2-p22.1. American Journal of Human Genetics, 63 (6), 1757-1766. doi: 10.1086/302152

Zollino, M., Seminara, L., Orteschi, D., Gobbi, G., Giovannini, S., Della Giustina, E., et al. (2009). The ring 14 syndrome: clinical and molecular definition. American Journal of Medical Genetics Part A, 149A (6), 1116-1124. doi: 10.1002/ajmg.a.32831 